\title{
ASSOCIATION BETWEEN VITAMIN D-BINDING PROTEIN (VDBP) GENE POLYMORPHISM AND VITAMIN D STATUS IN YOUNG CHILDREN
}

Mariia Romanko ${ }^{1}$, Zoia Rossokha² ${ }^{2}$ Iryna Maydan ${ }^{3}$, Maryna Mamenko ${ }^{4}$, Lyudmila Kvashnina ${ }^{5}$

${ }^{1}$ Department of Pediatrics No. 2, Shupyk National Medical Academy of Postgraduate Education, Kyiv, Ukraine mariaromanko1986@icloud.com

ORCID: http://orcid.org/0000-0003-1603-9471

${ }^{2}$ State Institution «Reference Center for Molecular Diagnostics of the Ministry of Health of Ukraine»., Kyiv, Ukraine zoiroh071@gmail.com

ORCID: http://orcid.org/0000-0002-4767-7364

${ }^{3}$ Department of Healthy Child Problems and Premorbid Conditions, State Institution «Institute of Pediatrics Obstetrics and Gynecology named Academic E. M. Lukyanova National Academy of Medical Sciences of Ukraine», Kyiv, Ukraine irynamaydan@gmail.com

ORCID: https://orcid.org/0000-0001-7623-6712

${ }^{4}$ Department of Pediatrics No. 2, Shupyk National Medical Academy of Postgraduate Education., Kyiv, Ukraine

mamenko.marina@gmail.com

ORCID: http://orcid.org/0000-0001-7487-2993

${ }^{4}$ Department of Healthy Child Problems and Premorbid Conditions, State Institution «Institute of Pediatrics Obstetrics and Gynecology named Academic E. M. Lukyanova National Academy of Medical Sciences of Ukraine», Kyiv, Ukraine 4839056@ukr.net

ORCID: http://orcid.org/0000-0001-7826-4880

\begin{tabular}{|c|c|}
\hline & ARTICLE INFO \\
\hline & Article history: \\
\hline & Received date 17.11.2019 \\
\hline & Accepted date 23.12.2020 \\
\hline & Published date 30.12 .2020 \\
\hline & Section: \\
\hline & Practical medicine \\
\hline & DOI \\
\hline
\end{tabular}

$10.21303 / 2313-8416.2020 .001557$

KEYWORDS

VDBP gene polymorphism

vitamin D

young children

\section{A B S T RAC T}

Object of the research: VDBP gene polymorphism.

Problem being addressed: the effect of existing polymorphic variants of the VDBP gene on the absorption of vitamin D in young children.

The main scientific results. At the beginning of the survey, vitamin D supplementation was performed in $50.0 \pm 9.1 \%(15 / 30)$ of children. The concentration of $25(\mathrm{OH}) \mathrm{D}$ in the serum of the subjects was $32.9 \mathrm{ng} / \mathrm{ml}$ (23.2-60.0). All patients with the GG rs 7041 genotype of the VDBP gene had a concentration of $25(\mathrm{OH}) \mathrm{D}$ in the range of $20-100 \mathrm{ng} / \mathrm{ml}$, which is statistically more common than in children with the AA rs 4588 genotype ( $p=0.015)$, GT rs 7041 genotype $(p=0.047)$ and genotype TT rs $7041(p=0.033)$. Patients with CA rs 4588 genotype $23.7 \mathrm{ng} / \mathrm{ml}(14.8-35.8)$ and GT rs $7041-28.1 \mathrm{ng} / \mathrm{ml}(17.1-49)$ had the lowest serum levels of $25(\mathrm{OH}) \mathrm{D}$, the highest levels of $25(\mathrm{OH}) \mathrm{D}$ - children with genotype AA rs $4588-122.6 \mathrm{ng} / \mathrm{ml}$ (23.2-124.1) and genotype TT rs $7041-78.6 \mathrm{ng} / \mathrm{ml}$ (23.2 -124.1). Carriers of the AA rs 4588 genotype were more likely than patients with the GG rs 7041 genotype to show dangerously high levels of $25(\mathrm{OH}) \mathrm{D}(p=0.069)$. Patients with the AA rs 4588 genotype had lower alkaline phosphatase levels compared to the GT rs 7041 and CC rs 4588 genotypes - $185.0 \mathrm{U} / 1$ (147.0 212.0 ) versus $259.5 \mathrm{U} / 1(207.0-334.5), p=0.021$ and against $251.0 \mathrm{U} / 1(222.0-346.0), p=0.016$. Area of practical application of research results: The results of the study can be used by working groups to make recommendations for the prevention and treatment of vitamin D deficiency and in the practice of health care facilities.

Innovative technological product: association between allelic variants of the VDBP gene and vitamin D status in young children.

Scope of application of innovative technological product: pediatrics, medical genetics. Conclusions. Genetic variants of VDBP may affect the absorption of vitamin D and cause variability in $25(\mathrm{OH}) \mathrm{D}$ levels, which complicates the development of uniform recommendations for optimal prophylactic doses of vitamin D and necessitates additional research. The highest levels of $25(\mathrm{OH}) \mathrm{D}$ were recorded in children with genotypes AA rs 4588 and TT rs 7041 of the VDBP gene, which showed high absorption when taking vitamin D supplements at a dose of $500 \mathrm{IU} / \mathrm{d}$ and even excessive concentrations of $25(\mathrm{OH}) \mathrm{D}$ with long-term supplementation in higher dose.

(C) The Author(s) 2020. This is an open access article under the CC BY license http://creativecommons.org/licenses/by/4.0).

\section{Introduction}

1. 1. Object of the research

Polymorphism of the VDBP gene in young children. 


\section{2. Description of the problem}

Vitamin D-binding protein (VDBP, vitamin D-binding protein, GS-globulin), which was identified in 1959, is one of the most common whey proteins and provides transport of about $90 \%$ of circulating metabolites of vitamin D [1,2] located in chromosome 4q11-q13 and consists of 13 exons encoding 474 amino acid sequences [3]. VDBP is one of the main genes in which mutations can affect the concentration of $25(\mathrm{OH}) \mathrm{D}$ [4-6]. This is due to the fact that most vitamin $\mathrm{D}$ circulates in the blood in combination with GC (VDBP), which is present in plasma, cerebrospinal fluid, and in the process of metabolism is associated with various forms of vitamin D [7]. There are two known single nucleotide polymorphisms (SNPs) in exon 11 of the VDBP gene: rs 4588 and rs 7041 [8]. At present, the study of the relationship between the concentration of $25(\mathrm{OH}) \mathrm{D}$ in serum and allelic variants of SNP rs 4588, rs 7041 of the VDBP gene continues.

\section{3. Suggested way to solve the problem}

There is thought that because the concentration of $25(\mathrm{OH}) \mathrm{D}$ and the response to vitamin $\mathrm{D}$ supplementation are individual, the optimal dose of cholecalciferol for young children may also depend on genotype $[4,9,10]$.

Analysis of the results of most recent studies on the effectiveness of vitamin D supplementation according to VDBP polymorphism indicates that individuals with genetic risk factors require higher doses of vitamin $\mathrm{D}[4,8]$.

Today, the discussion on determining the optimal prophylactic doses of vitamin D, including taking into account the different responses of individuals to supplementation, continues to study the factors that may affect the absorption of vitamin D, including genetic.

Despite numerous studies in this area, there is a lack of data that would apply to young children. There are also insufficient data on the prevalence of different allelic variants of the VDBP gene among the population of Ukraine.

The aim of the research: to study the association between existing allelic variants of the VDBP gene and vitamin D status in young children.

\section{Materials and methods}

The study was carried out on the basis of Communal non-profit enterprise "Kyiv City Children's Clinical Hospital No. 1" in 2017-2018 after receiving the opinion of the Commission on Bioethics at the National Medical Academy named after P. L. Shupyk and at the medical institution where the study was conducted. The study was conducted in accordance with the ethical principles of medical research conducted on people, which were adopted by the Declaration of Helsinki in 2008. The protocol of the study was agreed for all participants.

Thirty children (continuous sample) aged from 4 months to 3 years were included in the survey. After providing detailed information about the study and obtaining prior consent to participate in it, the children's parents were surveyed using a specially designed questionnaire, which identified risk factors for vitamin D deficiency.

According to the inclusion/exclusion criteria, the study did not include patients with manifest signs of rickets, children born prematurely, with intrauterine growth retardation, developmental defects, signs of immunosuppressive conditions, contraindications to vitamin $\mathrm{D}$, and children whose parents did not provide written consent for further participation of children in the study.

In the second stage, all children were tested for levels of $25(\mathrm{OH}) \mathrm{D}$, total calcium and ionized, inorganic phosphorus, alkaline phosphatase, serum Ig A and total Ig E levels (laboratory LLC "New Diagnostics", license AB 539668 from 22.04.10, Certificate of registration No. 12651020000001838 from 20.10.04) and molecular genetic study of polymorphic variants of the VDBP gene (rs 4588 and rs 7041) (SI "Reference Center for Molecular Diagnostics of the Ministry of Health of Ukraine").

Determination of serum level $25(\mathrm{OH}) \mathrm{D}$ was performed by electrochemiluminescence method on the Elecsys 2010 analyzer (RocheDiagnostics, Germany) using Cobas test systems.

Peripheral blood for molecular genetic testing was collected in $3 \mathrm{ml}$ vacuum Monovette with potassium salt of ethylenediaminetetraacetic acid as an anticoagulant (Vacutest, Italy) and frozen at $-20^{\circ} \mathrm{C}$. Transportation to the laboratory was performed in a thermobag with refrigerants. 
A commercial DNA-sorb-B nucleic acid extraction kit (AmpliSens) was used to isolate genomic deoxyribonucleic acid.

Molecular genetic study of polymorphic variants of the VDBP gene (rs 4588 and rs 7041) was performed using modified protocols by PCR followed by analysis of RFLP.

The amplification reaction was performed in an amplifier "FlexCyclerBU" (AnalyticJena, Germany). Specific fragments were amplified using primers manufactured by Metabion (Germany) and a commercial PCR kit Master Mix PCR ("NEOGEN", Ukraine). The amplification products of deoxyribonucleic acid fragments (amplicons) were subjected to hydrolytic cleavage by restriction endonucleases StyI (rs 4588) and HaeIII (rs7041) ("ThermoScientific", USA), respectively. Restriction was performed in a TDB-120 microthermostat ("Biosan", Latvia) at $37^{\circ} \mathrm{C}$ for 12 hours and stopped at $65{ }^{\circ} \mathrm{C}$ for 20 minutes for rs 4588 polymorphism and $80{ }^{\circ} \mathrm{C}$ for rs 7041 . The state of the restriction fragments was analyzed in a $3 \%$ agarose gel (agarose from "Cleaver Scientific", UK) with the addition of ethidium bromide using a transilluminator manufactured by "Cleaver Scientific", UK (Fig. 1, 2).

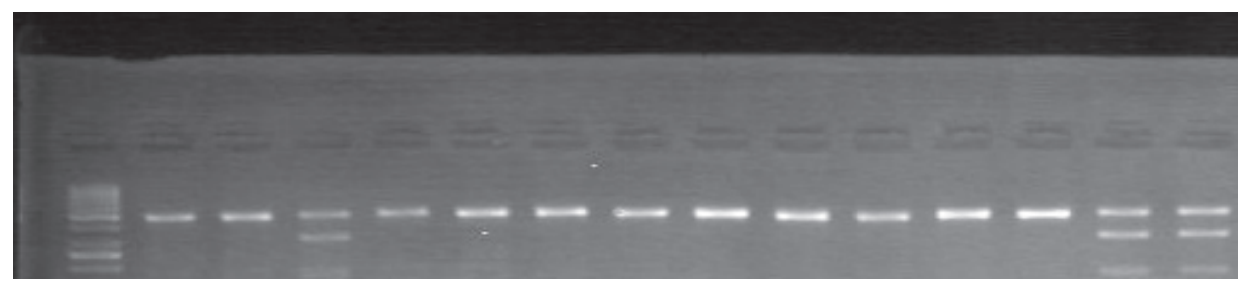

Fig. 1. Electrophoregram of the distribution of restriction fragments of the rs 4588 polymorphism of the VDBP gene: sample 1 - molecular weight marker; samples 2-3, 5-13, 19 - CC genotype; samples 4, 14-18-CA genotype

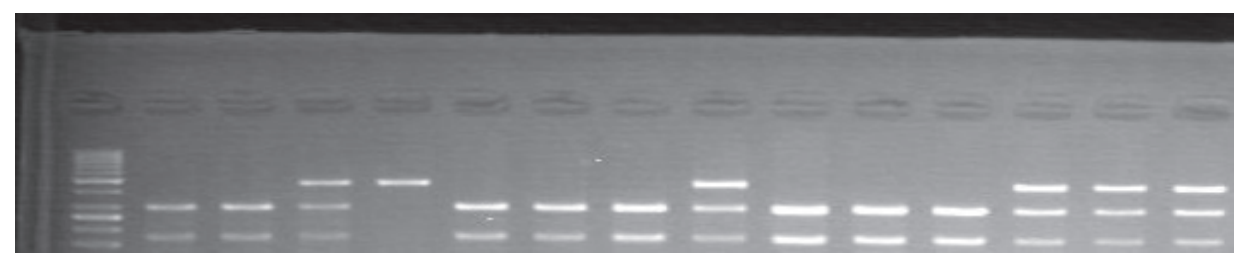

Fig. 2. Electrophoregram of the distribution of restriction fragments of the rs 7041 polymorphism of the VDBP gene: sample 1 - molecular weight marker; samples 2-3, 6-8, 10-12-genotype GG; samples 4, 9, 13-19-genotype GT, sample 5-genotype TT

The frequency distribution of alleles and genotypes rs 4588, rs 7041 of the VDBP gene in the examined children was compared with the data presented in the global database SNPedia (1000 genomes) [11].

The results of the study were statistically processed using standardized tools Microsoft Excel 2010 and the application package Statistica 10.0. The nature of the distribution was determined by the Shapiro-Wilk test. Qualitative indicators in the article are given in the form of absolute values and their errors $(M \pm m)$, of which relative (\%) are calculated, in the format $\mathrm{n} / \mathrm{N}$, where $\mathrm{n}$ is the number of cases, and $\mathrm{N}$ is the size of the corresponding group. Given the asymmetric nature of the distribution, descriptive statistics for quantitative indicators are presented in the form of median and interquartile range $-M e\left(Q_{1}-Q_{3}\right)$, where $M e$ is the median, $Q_{1} ; Q_{3}-25$ and 75 quartiles. Comparison of qualitative indicators was performed using Pearson's $\chi^{2}$ criterion. Quantitative indicators were evaluated according to the Mann-Whitney U criterion - for independent groups and the Wilcoxon criterion - for dependent groups. $P<0.05$ was taken as the critical level of significance when testing statistical hypotheses.

\section{Research results}

Among the patients included in the study, there were $36.7 \pm 8.8 \%(11 / 30)$ of boys and $63.3 \pm 8.8 \%(19 / 30)$ of girls $(\mathrm{p}=0.071)$. Most children were in the first $(36.7 \pm 8.8 \%)(11 / 30)$ and second year of life $(43.3 \pm 9.0 \%)(13 / 30), 20.0 \pm 7.3 \%(6 / 30)$ children were aged 2 to 3 years. 
It was found that at the beginning of the survey vitamin $\mathrm{D}$ supplementation was performed

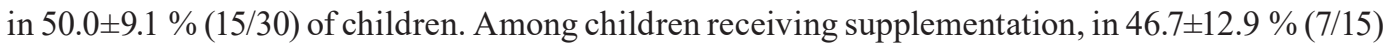
parents preferred an oil solution of cholecalciferol, and in $53.3 \pm 12.9 \%(8 / 15)$ - an aqueous solution, with a daily dose vitamin D was $500 \mathrm{IU} / \mathrm{d}$ in $40.0 \pm 12.6 \%(6 / 15), 1000 \mathrm{IU} / \mathrm{d}-$ in $60.0 \pm 12.6 \%(9 / 15)$ of children. No child received cholecalciferol at a dose greater than $1000 \mathrm{IU} / \mathrm{d}$. Children under 1 year of age received supplementation in $90.9 \pm 8.7 \%$ (10/11) of cases. In the second year of life, $38.5 \pm 13.5 \%(5 / 13)$ of the subjects received vitamin $\mathrm{D}$, and in the third year, supplementation was not performed on any child (0/4).

The median concentration of $25(\mathrm{OH})$ in the serum of the examined children was at the level of $32.9 \mathrm{ng} / \mathrm{ml}(23.2-60.0)$ with individual fluctuations from $6.6 \mathrm{ng} / \mathrm{ml}$ to $233.8 \mathrm{ng} / \mathrm{ml}$. The maximum level of $25(\mathrm{OH})$ was determined in a 4-month-old girl who had no risk factors for vitamin D deficiency, was exclusively breastfed, and regularly received an aqueous solution of cholecalciferol at a dose of 1000 IU from 1 month of age until enrolment. The status of vitamin D in patients included in the study was assessed according to official documents and classifications of leading international communities: Global consensus recommendations on prevention and management of nutritional rickets, American Academy of Pediatrics, Pediatric Endocrine Society, Canadian Pediatric Society [12-15].

As a result of molecular genetic study of polymorphic variants of the VDBP gene, it was found that the frequency of distribution of genotypes and alleles by polymorphism rs 4588 in the study group corresponded to Hardy-Weinberg law and did not differ significantly from world data $(p>0.05)$. However, compared to the international database, the TT rs $7041(p=0.005)$ and T allele rs $7041(p=0.000)$ genotypes were significantly more common in the examined children and the GG rs 7041 ( $p=0.003)$ and G genotypes were significantly less common allele rs $7041(p=0.000)$ (Table 1).

Table 1

Frequency distribution of alleles and genotypes rs 4588, rs 7041 of the VDBP gene in young children compared to the international database

\begin{tabular}{|c|c|c|c|c|c|c|}
\hline \multirow{2}{*}{ Polymorphism } & \multirow{2}{*}{ Genotypes } & \multicolumn{2}{|c|}{ Group of examined children } & \multicolumn{2}{|c|}{1000 genomes } & \multirow{2}{*}{$P$} \\
\hline & & $n=\mathbf{3 0}$ & $M \pm m(\%)$ & $n=503$ & $M \pm m(\%)$ & \\
\hline \multirow{5}{*}{ rs 4588} & $\mathrm{CC}$ & 15 & $50.0 \pm 9.1$ & 165 & $32.8 \pm 2.1$ & 0.083 \\
\hline & $\mathrm{CA}$ & 10 & $33.3 \pm 8.6$ & 257 & $51.1 \pm 2.2$ & 0.089 \\
\hline & AA & 5 & $16.7 \pm 6.8$ & 81 & $16.1 \pm 1.6$ & 0.862 \\
\hline & $\mathrm{C}$ allele & 40 & $66.7 \pm 6.1$ & 587 & $58.3 \pm 2.2$ & 0.256 \\
\hline & A allele & 20 & $33.3 \pm 6.1$ & 419 & $41.7 \pm 2.2$ & 0.256 \\
\hline \multirow{5}{*}{ rs 7041} & GG & 8 & $26.7 \pm 8.1$ & 281 & $55.9 \pm 2.2$ & 0.003 \\
\hline & GT & 16 & $53.3 \pm 9.1$ & 195 & $38.8 \pm 2.2$ & 0.164 \\
\hline & TT & 6 & $20.0 \pm 7.3$ & 27 & $5.4 \pm 1.0$ & 0.005 \\
\hline & $\mathrm{G}$ allele & 32 & $53.3 \pm 6.4$ & 757 & $75.2 \pm 1.9$ & 0.000 \\
\hline & T allele & 28 & $46.7 \pm 6.4$ & 249 & $24.8 \pm 1.9$ & 0.000 \\
\hline
\end{tabular}

It was found that there was a tendency to a higher frequency of the $\mathrm{T}$ allele rs 7041 in boys $(p=0.052)$. There was no gender difference in the frequency distribution of other alleles and genotypes by polymorphisms rs 4588 , rs 7041 of the VDBP gene $(p>0.05)$.

Patients with CA rs 4588 genotypes - $23.7 \mathrm{ng} / \mathrm{ml}(14.8-35.8)$ Dand GT genotype rs 7041 $28.1 \mathrm{ng} / \mathrm{ml}(17.1-49)$ had the lowest serum levels of $25(\mathrm{OH})$, and the highest levels were recorded in children with genotype AA rs $4588-122.6 \mathrm{ng} / \mathrm{ml}(23.2-124.1)$ and genotype TT rs 7041-78.6 ng/ml (23.2-124.1) (Fig. 3).

In total, the examined children had 5 combinations of genotypes out of 9 possible. It was found that the genotype AA rs 4588 in $100 \%$ of cases was combined with the genotype TT rs 7041, and the genotype CA rs 4588 in $100 \%$ of cases was combined with the genotype GT rs 7041. The study did not reveal the following combinations of genotypes by polymorphisms rs 4588 and rs 7041 VDBP gene: CA/GG, CA/TT, AA/GG, AA/GT.

In the examined young children with a combination of $\mathrm{CA} / \mathrm{GT}$ genotypes, the lowest levels of $25(\mathrm{OH}) \mathrm{D}$ were recorded $-23.7 \mathrm{ng} / \mathrm{ml}(14.8-35.8)$, with $60.0 \pm 15.5 \%(6 / 10)$ children with this combination of genotypes had a low level of vitamin D $(<30 \mathrm{ng} / \mathrm{ml})$. Among children with this 
combination of genotypes, only one child (10.0土9.5\%) (1/10) never received vitamin D at all (level $25(\mathrm{OH}) \mathrm{D}-30.3 \mathrm{ng} / \mathrm{ml}) ; 40.0 \pm 15.5 \%$ (4/10) received cholecalciferol at the time of the survey, among them 2 children underwent supplementation at a dose of $1000 \mathrm{IU} / \mathrm{d}$ (at a dose of $1000 \mathrm{IU} / \mathrm{d}-$ level $25(\mathrm{OH}) \mathrm{D} 23.41 \mathrm{ng} / \mathrm{ml}$ and $51.37 \mathrm{ng} / \mathrm{ml}$; at a dose of $500 \mathrm{IU} / \mathrm{d}-19.49 \mathrm{ng} / \mathrm{ml}$ and $157.1 \mathrm{ng} / \mathrm{ml})$.

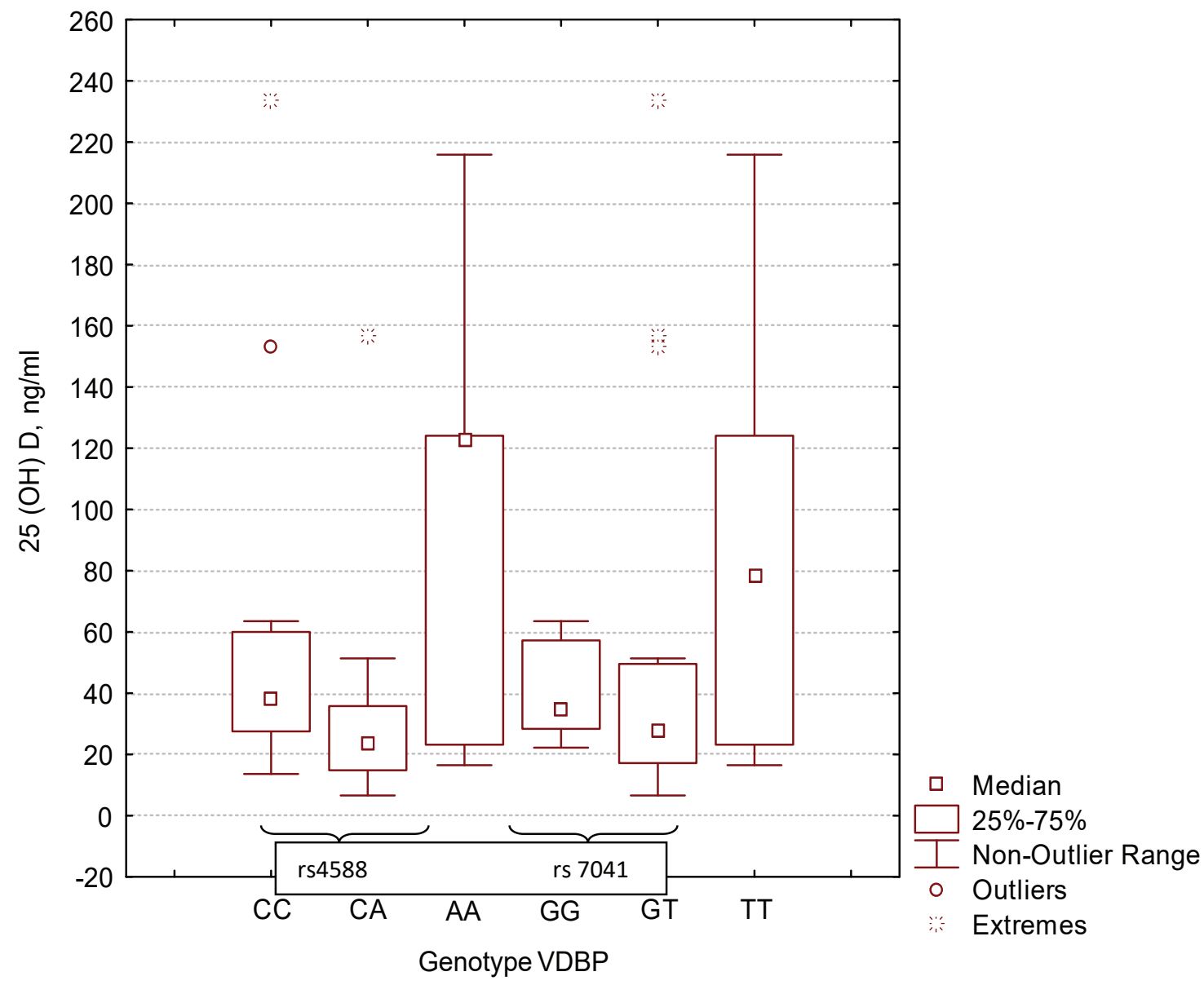

Fig. 3. The concentration of $25(\mathrm{OH}) \mathrm{D}$ in young children depending on the polymorphisms rs 4588 and rs 7041 of the VDBP gene

In the examined young children with a combination of CA/GT genotypes, the lowest levels of $25(\mathrm{OH}) \mathrm{D}$ were recorded - $23.7 \mathrm{ng} / \mathrm{ml}(14.8-35.8)$, with $60.0 \pm 15.5 \%(6 / 10)$ children with this combination of genotypes had a low level of vitamin D $(<30 \mathrm{ng} / \mathrm{ml})$. Among children with this combination of genotypes, only one child (10.0土9.5\%) (1/10) never received vitamin D at all (level $25(\mathrm{OH}) \mathrm{D}-30.3 \mathrm{ng} / \mathrm{ml}) ; 40.0 \pm 15.5 \%(4 / 10)$ received cholecalciferol at the time of the survey, among them 2 children underwent supplementation at a dose of $1000 \mathrm{IU} / \mathrm{d}$ (at a dose of $1000 \mathrm{IU} / \mathrm{d}-$ level $25(\mathrm{OH}) \mathrm{D} 23.41 \mathrm{ng} / \mathrm{ml}$ and $51.37 \mathrm{ng} / \mathrm{ml}$; at a dose of $500 \mathrm{IU} / \mathrm{d}-19.49 \mathrm{ng} / \mathrm{ml}$ and $157.1 \mathrm{ng} / \mathrm{ml})$.

The highest concentration was $25(\mathrm{OH}) \mathrm{D}$ in children with a combination of AA/TT genotypes $-122.6 \mathrm{ng} / \mathrm{ml}(23.2-124.1)$. The vast majority of carriers of this combination $(60.0 \pm 21.9 \%)$ $(3 / 5)$ recorded a level that, according to the Global consensus recommendations on prevention and management of nutritional rickets, is toxic $(>100 \mathrm{ng} / \mathrm{ml})$. These were children of the first year of life who were exclusively breastfed, received an aqueous solution of vitamin D and had no concomitant pathology. Two of them received supplementation of cholecalciferol at a dose of $500 \mathrm{IU} / \mathrm{d}$ (level $25(\mathrm{OH}) \mathrm{D}$ was $122.6 \mathrm{ng} / \mathrm{ml}$ and $124.1 \mathrm{ng} / \mathrm{ml}$, respectively), and one patient aged 4 months received vitamin D at a dose of $1000 \mathrm{IU} / \mathrm{d}$, with supplementation lasting only 2 months (concentration of $25(\mathrm{OH}) \mathrm{D}$ at the time of the initial examination in this child was $215.9 \mathrm{ng} / \mathrm{ml})$. Among the genes examined with this combination, two children were the exception - they had a concentration of this metabolite of vitamin D did not exceed $100 \mathrm{ng} / \mathrm{ml}$ : one child (33 months), supplementation was carried out only up to 12 months, and the other (9 months) - irregular taking the drug. 
Level $25(\mathrm{OH}) \mathrm{D}$, which exceeded $150 \mathrm{ng} / \mathrm{ml}(153.3 \mathrm{ng} / \mathrm{ml}$ and $233.8 \mathrm{ng} / \mathrm{ml})$, was recorded in two more patients who had a combination of genotypes CC/GT (33.3 $\pm 19.2 \%)(2 / 6)$. Both children were under 1 year of age and received supplementation at a dose of $1000 \mathrm{IU} / \mathrm{d}$ from 1 month of age until the initial examination.

The analysis of the level of vitamin D supply depending on the polymorphisms of the VDBP gene was performed. It was found that only carriers of genotypes CA rs 4588 and GT rs 7041 had severe vitamin D deficiency $(<10 \mathrm{ng} / \mathrm{ml})$, but no significant difference was obtained, which was probably due to insufficient sample size (Table 2).

\section{Table 2}

The level of vitamin D supply in young children depending on the polymorphism of the VDBP gene

\begin{tabular}{|c|c|c|c|c|c|c|c|}
\hline \multirow{2}{*}{$\begin{array}{l}\text { Name of official document or } \\
\text { professional organization (deficien- } \\
\text { cy/insufficiency/sufficiency/toxic } \\
\text { level, ng/ml) }\end{array}$} & \multirow[b]{2}{*}{$\%$} & \multicolumn{3}{|c|}{ Genotypes rs $4588(\%)$} & \multicolumn{3}{|c|}{ Genotypes rs $7041(\%)$} \\
\hline & & $\mathbf{C C}$ & $\mathbf{C A}$ & AA & GG & GT & TT \\
\hline \multicolumn{8}{|c|}{ Global consensus recommendations on prevention and management of nutritional rickets } \\
\hline$<12$ & $6.7 \pm 4.6$ & 0 & $20.0 \pm 12.6$ & 0 & 0 & $12.5 \pm 8.3$ & 0 \\
\hline $12-20$ & $13.3 \pm 6.2$ & $6.7 \pm 6.5$ & $20.0 \pm 12.6$ & $20.0 \pm 17.9$ & 0 & $18.7 \pm 9.7$ & $16.7 \pm 15.2$ \\
\hline$>20$ & $80.0 \pm 7.3$ & $93.3 \pm 6.5$ & $60.0 \pm 15.5$ & $80 \pm 17.9$ & 100 & $68.8 \pm 11.6$ & $83.3 \pm 15.2$ \\
\hline$>100$ & $20.0 \pm 7.3$ & $13.3 \pm 8.8$ & $10.0 \pm 9.5$ & $60.0 \pm 21.9 \#$ & 0\# & $18.7 \pm 9.7$ & $50.0 \pm 20.4$ \\
\hline \multicolumn{8}{|c|}{ American Academy of Pediatrics } \\
\hline$<20$ & $20.0 \pm 7.3$ & $6.7 \pm 6.5$ & $40.0 \pm 15.5$ & $20.0 \pm 17.9$ & 0 & $31.3 \pm 11.6$ & $16.7 \pm 15.2$ \\
\hline $20-30$ & $23.3 \pm 7.7$ & $26.7 \pm 11.4$ & $20.0 \pm 12.6$ & $20.0 \pm 17.9$ & $37.5 \pm 17.1$ & $18.7 \pm 9.7$ & $16.7 \pm 15.2$ \\
\hline$>30$ & $56.7 \pm 9.0$ & $66.6 \pm 12.2$ & $40.0 \pm 15.5$ & $60.0 \pm 21.9$ & $62.5 \pm 17.1$ & $50.0 \pm 12.5$ & $66.6 \pm 19.3$ \\
\hline \multicolumn{8}{|c|}{ Pediatric Endocrine Society } \\
\hline$<15$ & $13.3 \pm 6.2$ & $6.7 \pm 6.5$ & $30.0 \pm 14.5$ & 0 & 0 & $25.0 \pm 10.8$ & 0 \\
\hline $15-20$ & $6.7 \pm 4.6$ & 0 & $10.0 \pm 9.5$ & $20.0 \pm 17.9$ & 0 & $6.3 \pm 6.1$ & $16.7 \pm 15.2$ \\
\hline $20-100$ & $60.0 \pm 8.9$ & $80 \pm 10.3$ & $50.0 \pm 15.8$ & $20.0 \pm 17.9^{*}$ & $100 * / * * / * * *$ & $50.0 \pm 12.5^{* * *}$ & $33.3 \pm 19.2^{* *}$ \\
\hline$>150$ & $13.3 \pm 6.2$ & $6.7 \pm 6.5$ & $10.0 \pm 9.5$ & $20.0 \pm 17.9$ & 0 & $18.7 \pm 9.7$ & $16.7 \pm 15.2$ \\
\hline \multicolumn{8}{|c|}{ Canadian Pediatric Society } \\
\hline$<10$ & $6.6 \pm 4.5$ & 0 & $20.0 \pm 12.6$ & 0 & 0 & $12.5 \pm 8.3$ & 0 \\
\hline $10-30$ & $36.7 \pm 8.8$ & $33.3 \pm 12.2$ & $40.0 \pm 15.5$ & $40.0 \pm 21.9$ & $37.5 \pm 17.1$ & $37.5 \pm 12.1$ & $33.3 \pm 19.2$ \\
\hline $30-90$ & $36.7 \pm 8.8$ & $53.3 \pm 12.9$ & $30.0 \pm 14.5$ & 0 & $62.5 \pm 17.1$ & $31.3 \pm 11.6$ & $16.7 \pm 15.2$ \\
\hline$>200$ & $6.6 \pm 4.5$ & $6.7 \pm 6.5$ & 0 & $20.0 \pm 17.9$ & 0 & $6.3 \pm 6.1$ & $16.7 \pm 15.2$ \\
\hline
\end{tabular}

Note: *-the probability of differences $(p<0.05)$ between children with genotype GG rs 7041 and patients with genotype AA rs 4588; ** - probability of differences $(p<0.05)$ between children with GG rs 7041 genotype and patients with TT rs 7041 genotype; *** - probability of differences $(p<0.05)$ between children with genotype GG rs 7041 and patients with genotype GT rs 7041; \#-probability of differences $(p<0.05)$ between children with genotype AA rs 4588 and patients with genotype GG rs 7041

All children with the GG rs 7041 genotype of the VDBP gene had a concentration of 25 $(\mathrm{OH}) \mathrm{D}$ in the range of $20-100 \mathrm{ng} / \mathrm{ml}$, which is statistically more common than in children with the AA rs 4588 genotype $(p=0.015)$, GT rs 7041 genotype=0.047) and the TT genotype rs 7041 $(p=0.033)$. At the time of inclusion in the study, $37.5 \pm 17.1 \%(3 / 8)$ of these patients received vitamin D at a dose of $1000 \mathrm{IU} / \mathrm{d}$. Carriers of the AA rs 4588 genotype showed dangerously high levels of $25(\mathrm{OH}) \mathrm{D}(p=0.069)$ more often than patients with the GG genotype rs 7041 .

Analysis of other indicators of phosphorus-calcium metabolism depending on polymorphic variants of the VDBP gene showed that patients with the AA rs 4588 genotype had lower levels of alkaline phosphatase compared to children with the GT rs 7041 and CC rs 4588 genotypes - 185.0 $\mathrm{U} / 1$ (147.0-212.0) against 259.5 U/1 (207.0-334.5), $p=0.021$ and against 251.0 U/1 (222.0-346.0), $p=0.016$. This can be explained by significantly higher levels of $25(\mathrm{OH}) \mathrm{D}$ in children with the AA rs 4588 genotype, compared with patients with the GT rs 7041 and CC rs 4588 genotypes.

\section{Discussion of research results}

Thus, a study examining the relationship between VDBP gene polymorphism and vitamin D status in relatively healthy young children demonstrated the presence of different allelic 
variants of this gene in the population. Subjects with AA rs 4588 and TT rs 7041 genotypes of the VDBP gene had the highest serum $25(\mathrm{OH})$ D concentrations. Similar results were obtained in 2019 by M. Mehramiz et al., who investigated the effect of genetic polymorphisms of the VDBP gene at the level of $25(\mathrm{OH}) \mathrm{D}$ in 619 Iranian adolescent girls. Subjects received high doses of vitamin D (50,000 IU/week for 9 weeks). The results of the study showed that patients with the AA rs 4588 genotype of the VDBP gene responded better to vitamin D intake than children with the GG rs 7041 genotype [16].

At the same time, in a Greek study examining the association between serum $25(\mathrm{OH}) \mathrm{D}$ levels and VDR Apal, VDBP rs 4588 and rs 7041 polymorphisms in 69 children with bronchial asthma, the TT rs 7041 genotype of the VDBP gene, in contrast, associated with lower levels of 25 $(\mathrm{OH}) \mathrm{D}$ in these patients [17].

Study limitations. Because the results of this study are limited by the small sample power, and different researchers point to conflicting data, further studies in larger cohorts are needed. The presence of different allelic variants of the VDBP gene may explain the different responses of individual subjects to vitamin D supplementation and indicate the need to correct existing standards for the prevention and treatment of rickets and other pathological conditions associated with vitamin D deficiency.

Prospects for further research. The study of the prevalence of different allelic variants of the VDBP gene will clarify the data obtained on their association with the status of vitamin D, individualize and optimize approaches to supplementation and treatment of pathological conditions associated with vitamin D deficiency.

\section{Conclusions}

1. Performed tests indicate the presence of polymorphic variants of the VDBP gene in children in Ukraine, which may affect the effectiveness of prevention of rickets by supplementation of vitamin D.

2. Compared with the international database, the TT rs 7041 genotype $(p=0.005)$ and T allele rs 7041 genotype ( $p=0.000)$ were significantly more common in the examined children and the GG rs 7041 genotype $(p=0.003)$ and $\mathrm{G}$ allele rs 7041 genotype $(p=0.000)$ were significantly less common.

3. Optimal levels of $25(\mathrm{OH}) \mathrm{D}$ in serum, regardless of the dose of supplements, were demonstrated by all examined young children with genotype GG rs 7041 gene VDBP.

4. Low concentrations of $25(\mathrm{OH}) \mathrm{D}$ were determined mainly in the examined children with genotypes CA rs 4588 and GT rs 7041 of the VDBP gene.

5. The highest levels of $25(\mathrm{OH}) \mathrm{D}$ were recorded in children with genotypes AA rs 4588 and TT rs 7041 of the VDBP gene, which showed high absorption when taking vitamin D supplements at a dose of $500 \mathrm{IU} / \mathrm{d}$ and even excessive concentrations of $25(\mathrm{OH}) \mathrm{D}$ with long-term use supplements in a higher dose.

6. For final conclusions on the potential impact of VDBP gene polymorphism on the effectiveness of prevention of vitamin D deficiency, it is necessary to conduct research on large cohorts of children and adults in Ukraine.

\section{Conflict of interests}

The authors declare that they have no conflicts of interest.

\section{References}

[1] Al-Azzawi, M. A., Ghoneim, A. H., Elmadbouh, I. (2017). Evaluation of Vitamin D, Vitamin D Binding Protein Gene Polymorphism with Oxidant - Antioxidant Profiles in Chronic Obstructive Pulmonary Disease. Journal of Medical Biochemistry, 36 (4), 331-340. doi: http://doi.org/10.1515/jomb-2017-0012

[2] White, P., Cooke, N. (2000). The Multifunctional Properties and Characteristics of Vitamin D-binding Protein. Trends in Endocrinology \& Metabolism, 11 (8), 320-327. doi: http://doi.org/10.1016/s1043-2760(00)00317-9

[3] Bikle, D. D., Schwartz, J. (2019). Vitamin D Binding Protein, Total and Free Vitamin D Levels in Different Physiological and Pathophysiological Conditions. Frontiers in Endocrinology, 10. doi: http://doi.org/10.3389/fendo.2019.00317

[4] Enlund-Cerullo, M., Koljonen, L., Holmlund-Suila, E., Hauta-alus, H., Rosendahl, J., Valkama, S. et. al. (2019). Genetic Variation of the Vitamin D Binding Protein Affects Vitamin D Status and Response to Supplementation in Infants. The Journal of Clinical Endocrinology \& Metabolism, 104 (11), 5483-5498. doi: http://doi.org/10.1210/jc.2019-00630 
[5] Nissen, J., Rasmussen, L. B., Ravn-Haren, G., Andersen, E. W., Hansen, B., Andersen, R. et. al. (2014). Common Variants in CYP2R1 and GC Genes Predict Vitamin D Concentrations in Healthy Danish Children and Adults. PLoS ONE, 9 (2), e89907. doi: http://doi.org/10.1371/journal.pone.0089907

[6] Thongthai, P., Chailurkit, L., Chanprasertyothin, S., Nimitphong, H., Sritara, P., Aekplakorn, W., Ongphiphadhanakul, B. (2015). Vitamin D Binding Protein Gene Polymorphism as a Risk Factor for Vitamin D Deficiency in Thais. Endocrine Practice, 21 (3), 221-225. doi: http://doi.org/10.4158/ep14266.or

[7] Zelenskaya, E. M., Lifshits, G. I. (2018). Genetic background vitamin D deficiency and modern methods of its correction in children. Pharmacogenetics and Pharmacogenomics, 1, 21-26. doi: http://doi.org/10.24411/2588-0527-2018-10004

[8] Al-Daghri, N. M., Mohammed, A. K., Bukhari, I., Rikli, M., Abdi, S., Ansari, M. G. A. et. al. (2019). Efficacy of vitamin D supplementation according to vitamin D-binding protein polymorphisms. Nutrition, 63-64, 148-154. doi: http:/doi.org/ 10.1016/j.nut.2019.02.003

[9] Sollid, S., Hutchinson, M. Y., Fuskevåg, O., Joakimsen, R., Jorde, R. (2015). Large Individual Differences in Serum 25-Hydroxyvitamin D Response to Vitamin D Supplementation: Effects of Genetic Factors, Body Mass Index, and Baseline Concentration. Results from a Randomized Controlled Trial. Hormone and Metabolic Research, 48 (1), 27-34. doi: http://doi.org/ 10.1055/s-0034-1398617

[10] Didriksen, A., Grimnes, G., Hutchinson, M. S., Kjærgaard, M., Svartberg, J., Joakimsen, R. M., Jorde, R. (2013). The serum 25-hydroxyvitamin D response to vitamin D supplementation is related to genetic factors, BMI, and baseline levels. European Journal of Endocrinology, 169 (5), 559-567. doi: http://doi.org/10.1530/eje-13-0233

[11] Cariaso, M., Lennon, G. (2011). SNPedia: a wiki supporting personal genome annotation, interpretation and analysis. Nucleic Acids Research, 40 (D1), D1308-D1312. doi: http://doi.org/10.1093/nar/gkr798

[12] Munns, C. F., Shaw, N., Kiely, M., Specker, B. L., Thacher, T. D., Ozono, K. et. al. (2016). Global Consensus Recommendations on Prevention and Management of Nutritional Rickets. Hormone Research in Paediatrics, 85(2), 83-106. doi: http://doi.org/ $10.1159 / 000443136$

[13] Wagner, C. L., Greer, F. R. (2008). Prevention of Rickets and Vitamin D Deficiency in Infants, Children, and Adolescents. Pediatrics, 122 (5), 1142-1152. doi: http://doi.org/10.1542/peds.2008-1862

[14] Misra, M., Pacaud, D., Petryk, A., Collett-Solberg, P. F., Kappy, M. (2008). Vitamin D Deficiency in Children and Its Management: Review of Current Knowledge and Recommendations. Pediatrics, 122 (2), 398-417. doi: http://doi.org/10.1542/ peds.2007-1894

[15] Godel, J. C. (2007). Vitamin D supplementation: Recommendations for Canadian mothers and infants. Paediatrics \& Child Health, 12 (7), 583-589. doi: http://doi.org/10.1093/pch/12.7.583

[16] Mehramiz, M., Khayyatzadeh, S. S., Esmaily, H., Ghasemi, F., Sadeghi-Ardekani, K., Tayefi, M. et. al. (2019). Associations of vitamin D binding protein variants with the vitamin D-induced increase in serum 25-hydroxyvitamin D. Clinical Nutrition ESPEN, 29, 59-64. doi: http://doi.org/10.1016/j.clnesp.2018.12.005

[17] Iordanidou, M., Paraskakis, E., Giasari, G., Manolopoulos, V., Chatzimichael, A. (2014). VDR and VDBP polymorphisms are associated with $25(\mathrm{OH})$ D3 levels in asthmatic children. European Respiratory Journal, 44 (58). 